\title{
Isolation and Characterization of Indole Acetic Acid (IAA) Producing Tomato Rhizobacterium Pseudomonas sp VSMKU4050 and its Potential for Plant Growth Promotion
}

\author{
R. Kalimuthu ${ }^{1,2}$, P. Suresh ${ }^{2}$, G. Varatharaju², N. Balasubramanian³, \\ K.M. Rajasekaran ${ }^{1 *}$ and V. Shanmugaiah ${ }^{2 *}$
}

${ }^{1}$ Department of Botany, Madura College, Madurai - 625 011, Tamil Nadu, India

${ }^{2}$ Department of Microbial Technology, ${ }^{3}$ Department of Immunology, School of Biological

Sciences, Madurai Kamaraj University, Madurai - 625 021, Tamil Nadu, India

*Corresponding author

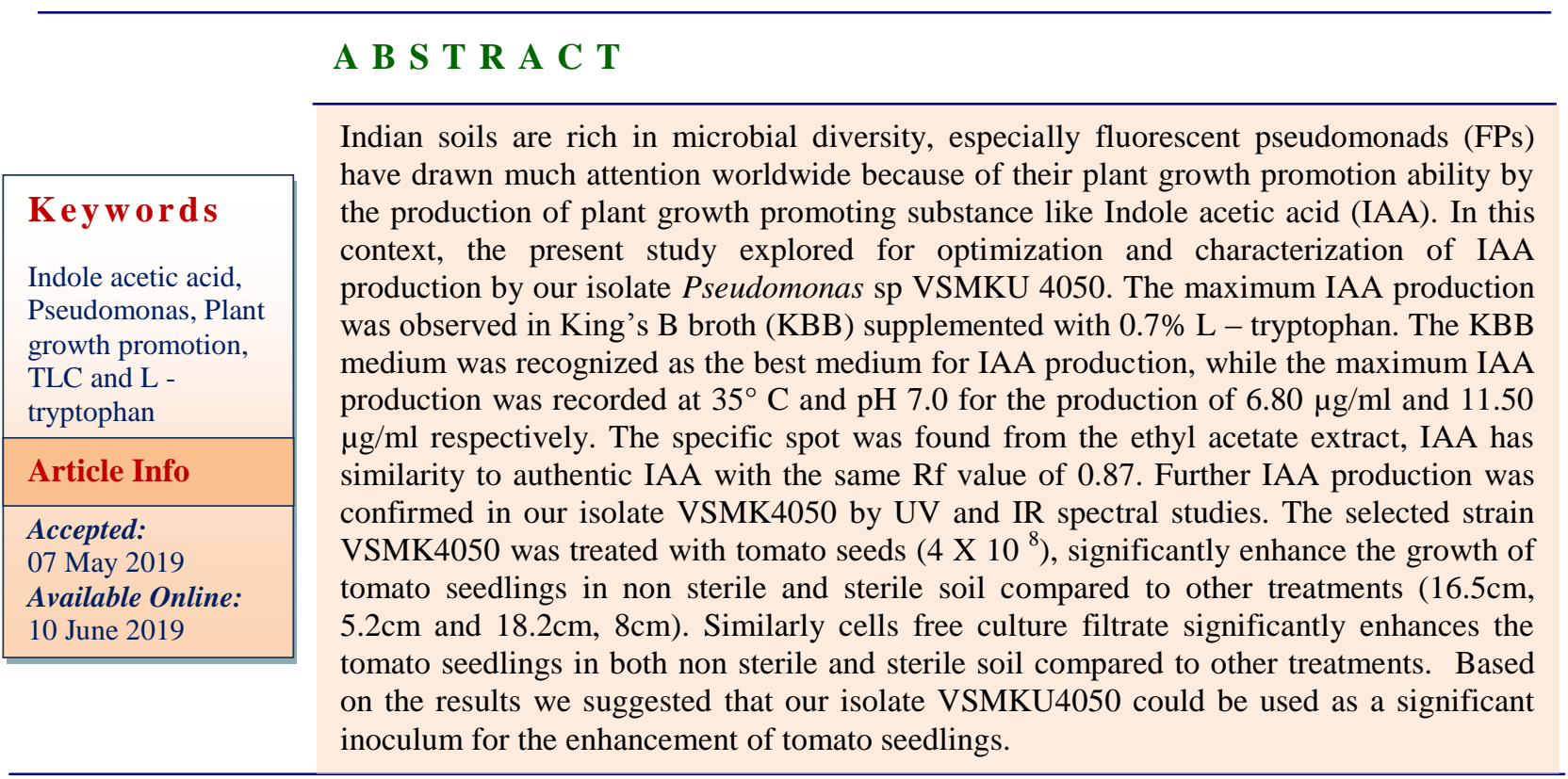

\section{Introduction}

In recent scenario FPs are act as a plant growth promoter, bio potential inoculums and biocontrol agents instead of using chemical fungicides, pesticides and herbicides, because almost $99 \%$ of bioinoculum could be degradable, hence it could not cause environmental pollution and health hazards. In this context taking in to consideration of synthetic chemicals, the alternative choice is biofertilizers are supposed to be a safe and healthy environment compared to chemical inputs and minimizes environmental problem to a great extent. Biofertilizers from microbes are ecofriendly method of agriculture, at the 
same time cost- effective than chemical fertilizers, and their prolonged use enhances soil fertility substantially (Mahdi et al., 2010; Singh et al., 2011). Moreover, plant rhizosphere have rich microbial diversity and wealth of indigenous micro flora, hence it has to be need more attention for antagonistic microbes to explore for potential plant growth promotion and developing as bio- inoculants for interact with plant roots and enhancement of yield of economically important food crops (Shanmugaiah et al., 2010).

Most of the beneficial rhizobacteria inhabit the area around the plant roots or in plant tissues and stimulate plant growth directly or indirectly. Antagonistic microorganisms are synthesis of the phytohormone Indole-3acetic acid (IAA) is one of the direct effects of PGPR on plant growth (Yousef, 2018). Many proteobacteria especially rhizosphere inhabitant belonging to the genera Azospirillum, Pseudomonas, Streptomyces sp. and Rhizobium as well as Enterobacter cloacae, Acetobacter diazotrophicus and radyrhizobium japoicum have been shown to produce auxins which help in stimulating plant growth (Patten and Glick, 1996, Shanmugaiah et al., 2013, Harikrishnan et al., 2014). A. brazilense, inoculation in wheat seedlings improved the number and length of lateral roots (Barbieri et al., 1986). Inoculation of canola seeds with Pseudomonas putida GR12-2, which produces low levels of IAA, resulted in 2 to 3 fold increase in the length of seedling roots (Glick et al., 1986). It is assumed that plant growth regulators produced by Pseudomonas species could also influence plant growth.

Rhizobacteria and soil-borned bacteria augment plant intensification by many mechanisms referred to as Plant Growth Promoting Rhizobacteria (PGPR) (Ahemad and Kibert, 2014) and other mechanism such as nutrient acquisition and plant disease suppression. PGPR inhabit soil born pathogens and rhizosbacteria are capable of producing plant growth regulators such as auxin, gibberellins and ethylene. Indole acetic acid is a naturally occurring auxin which involves in cellular development and physiological processes in plants. Different soil microorganisms including bacteria (Stein et al., 1990), fungi (Finnie and Van Staden, 1985) and algae (Rifat Hayat et al., 2010) are capable of producing physiologically active quantities of auxins, which may exert prominent effects on plant growth and development. Beneficial effects of this microbe, such as increased plant growth and enhanced plant resistance to an array of pathogens and to drought stress, require effective root colonization and the production of secondary products (Spencer et al., 2003).

The application of single and combined application of rhizosphere and talc formulated microbes could increase plant growth of cotton, green gram and sorghum due to result of slightly deleterious effect of strain causing increased root leakage or damage, which allows a greater population of aggressive rhizosphere and root colonizers such as Trichoderma viride and Pseudomonas fluorescence (Shanmugaiah et al., 2009). Since IAA has been found to be very important for plant growth and development, extensive studies have been performed on IAA after it discovery as a plant hormone. IAA synthesized by plants and microbes through different inter linked pathways of which tryptophan depended pathway is the best under stood (Zhao, 2010). Indole-3-acetic acid does not function as a hormone in bacterial cells but their ability to produce the same may have evolved as it is important in plant-bacteria relationship (Patten and Glick, 2002). Bacterial auxins have the possible to change any of these functions by altering the plant auxin collection. It depends on the total of IAA produced and the sensitivity of plant tissue to changing levels of IAA. The roots are the most sensitive organs and respond to 
the changing levels of IAA by elongation of primary roots, formation of adventitious and lateral roots, or cessation growth.

Indole-3-acetic acid does not function as a hormone in bacterial cells but their ability to produce the same may have evolved as it is important in plant-bacteria relationship (Patten and Glick, 2002). In the present study, we report for optimization of IAA production by Pseudomonas sp VSMKU4050 isolated from the rhizospheric soils of tomato (Solanum lycopersicum).

\section{Materials and Methods}

\section{Acquirance of Pseudomonas \\ VSMKU4050 and their maintenance}

sp

The selected strain VSMKU4050 was obtained from the Department of Microbial Technology, School of Biological Sciences, Madurai Kamaraj University, Madurai- 625 021, Tamil Nadu, India. For identification of VSMKU4050, we have done Morphological observation and biochemical analysis (Gram's staining, catalase, oxidase, citrate and urea utilization, nitrate reduction, indole production, VP, TSI, carbohydrate utilization and hydrolytic enzyme production). The selected strain VSMKU4050 was stored at $80^{\circ} \mathrm{C}$ with $30 \%$ glycerol stock for long term storage for future studies.

\section{IAA production}

IAA production was performed by the method of Shanmugaiah et al., (2008) with slight modifications. Pseudomonas sp VSMKU4050 isolate $100 \mu \mathrm{l}$ culture were inoculated in King's B broth supplemented with $0.3 \%$ filter sterilized $(0.2 \mu \mathrm{m}$ membrane filter, Whatmann) L- tryptophan solution and incubated at $28^{\circ} \mathrm{C}$ in a rotary shaker at 140 rpm for two days. After two days of incubation, the culture was centrifuged at 10, $000 \mathrm{rpm}$ for $20 \mathrm{~min}$. One milliliter of cell free supernatant was mixed with $2 \mathrm{ml}$ of Salkowski reagent $(1 \mathrm{ml}$ of $0.5 \mathrm{M} \mathrm{FeCl} 3$ in 50 $\mathrm{mL}$ of $35 \% \mathrm{HClO} 4)$ and incubated for $1 \mathrm{hr}$. Development of pink colour indicated the production of IAA.

The characterization of IAA was performed by UV- spectrophotometer and IR- spectrum. A standard curve was plotted for quantification of IAA solution and uninoculated medium with a reagent was maintained as control. The amount of IAA in the culture was expressed as $\mu \mathrm{g} / \mathrm{ml}$ compared to control.

\section{Optimization of IAA production}

The production of IAA was performed for the selected isolate VSMKU4050 by one factor at a time was employed in this present study.

\section{Effect of L-tryptophan concentration}

The effect of L-tryptophan concentrations for IAA production was studied using King's B broth supplemented with L-tryptophan at different concentrations $(0.1-1.0 \mathrm{gm} / \mathrm{ml})$ and followed by $\mathrm{pH}$ 7.0. The culture was incubated at $37^{\circ} \mathrm{C}$ in an environmental shaker at $140 \mathrm{rpm}$ for six days.

\section{Effect of incubation time}

The selected strain Pseudomonas sp. VSMKU4050 was incubated for IAA production in $50 \mathrm{ml}$ of King's B broth supplemented with $0.7 \mu \mathrm{g} / \mathrm{ml} \mathrm{L}$ - tryptophan at $\mathrm{pH} 7.0$ and incubated at $37{ }^{\circ} \mathrm{C}$ in a shaker at $140 \mathrm{rpm}$ for six days.

IAA production was assayed by incubating the selected strain VSMKU4050 culture under optimum conditions up to three days. Production of IAA and residual L- tryptophan was measured at every $24 \mathrm{~h}$ interval.

\section{Effect of temperature and $\mathrm{pH}$}


The optimum level of $\mathrm{pH}$ for the production of IAA by the selected strain Pseudomonas sp.VSMKU4050 was determined with different $\mathrm{pH}$ from 2 - 10. Similar experiments were performed to evaluate the effect of temperature by the above said culture was incubated with a different temperature at 15 $45^{\circ} \mathrm{C}$ respectively.

\section{Extraction of IAA}

The extraction of Indole acetic acid from Pseudomonas sp. VSMKU4050 was carried out by the normal solvent extraction method with slight modification (Charulatha et al., 2013, Harikrishnan et al., 2014).

\section{Detection of IAA on TLC}

The extracted ethyl acetate fraction of crude compounds was performed using pre-coated silica gel TLC plates of grade F274 (EMerck, Germany) to detect IAA compounds produced by our isolate VSMKU4050. The crude extract was spotted with capillary tube and solvent front was allowed to run for approximately $80 \%$ of the plate. The crude was eluted with butanone-ethyl acetateethanol-water (3:5:1:1) solvent system, similar solvent system was used for the detection and comparison of commercial IAA on TLC. Finally both samples spot on TLC were examined under UV light $(254 \mathrm{~nm})$ and by spraying on the plates with Ehmann reagent (Ehmann, 1977).

\section{Characterization of IAA by spectral studies}

The partially purified IAA was used for IAA characterization and commercial IAA was used as a standard control. The eluted plates were dried completely and visualized under $\mathrm{UV}$ and iodine subsequently; the movement of the crude IAA along with solvent was measured (Rf value). The IAA was dissolved in ethyl acetate and it was observed in
UV/VIS spectrophotometer (Shimadzu 1800, Kyoto, Japan) between 200 and 400nm after calibration with ethyl acetate as a blank. Fourier Transform- Infra Red spectrum was recorded in $400-4000 \mathrm{~cm}-1$ in dry chloroform solution using a FT- IR machine (Shimadzu 8400S, Japan).

Effect of Pseudomonas sp. VSMKU4050 for Plant Growth Promotion of Tomato seedlings

The ability of plant growth promotion of the isolate Pseudomonas sp VSMKU4050 was evaluated in In vitro conditions using sterile and non sterile soil. Tomato seeds (Cherry) were surface sterilized with $0.1 \%$ (w/v) $\mathrm{HgCl}_{2}$ for $5 \mathrm{~min}$ and washed thoroughly with double sterile water. Air dried Tomato seeds were soaked in $10^{8}$ culture suspension, cell free culture filtrate of VSMKU4050 for 30min and placed in pots. King's B broth was included as control. After 30 days, seeds germination, the root and shoot length, fresh and dry weight was measured (Shanmugaiah et al., 2008).

\section{Statistical analysis}

Values were given as means \pm SD for triplicate experiments.

\section{Results and Discussion}

\section{Isolation and identification of selected} isolate VSMKU4050

The selected strain VSMKU4050 based on the morphological observation, bio physio chemical test, the selected isolate VSMKU4050 was identified as Pseudomonas sp. The identified strain designated as VSMKU4050 was chosen for IAA production based on its antagonistic potential and plant growth promotion efficiency (Table 1). IAA is one of important component of Ltryptophan metabolism produced by various 
microbial floras including plant growth promoting rhizobacteria (PGPR) (Lynch, 1985). PGPR have the capacity to colonize the rhizosphere and plant roots, at the same time, they could have enhance plant growth by different mechanism are referred to as PGPR. PGPR can demonstrate a variety of uniqueness responsible for influencing plant growth. The common character includes production of plant growth regulators such as, IAA, gibberellin, and ethylene, siderophores, HCN and antibiotics (Arshad et al., 1992, Harikrishnan et al., 2014). In recent days researchers revealed that IAA producing more organisms were belonged to Gram negative (Datta and Basu, 2000). More over little group Gram positive especially belong to Bacillus sp. known to produce IAA (Wahyudi et al., 2011). Based on the literature survey and our observation, showed almost $90 \%$ of rhizospheric associated microbes are capable for production of IAA. Among them Gram negative bacteria predominantly produced IAA compared to Gram positive bacterial groups.

\section{Effect of L- tryptophan concentration on IAA production}

The production of IAA was performed with different concentrations of L- tryptophan between 0.1 to $10 \%$. The spectrophotometric analysis was showed that gradual increase in the IAA production with respective substrate L- tryptophan concentration. However, $0.7 \%$ of L- tryptophan was observed maximum IAA production compared to control with other concentration of IAA. The maximum level of IAA production was observed as $12.80 \mu \mathrm{g} / \mathrm{ml}$ when $0.7 \% \quad$ L-tryptophan concentration was amended in the medium King's B broth compared with control (Figure 1). Our results for IAA production by isolate VSMKU4050 in accordance with previous report, because L-tryptophan is considered as a precursor for IAA production because its addition to medium increases IAA production (Santi et al., 2007). The maximum IAA production was observed as $15.96 \mu \mathrm{g} / \mathrm{ml}$ when $0.5 \%$ L-tryptophan concentration was amended in the medium compared with known IAA standard (Harikrishnan et al., 2014). Our study shows similar trend of result when increase the concentration of Ltryptophan, the spectrophometric analysis showed gradual increase in the IAA production with the increase in L-tryptophan concentration. $0.2 \mathrm{mg} / \mathrm{ml}$ of L-tryptophan concentration in the medium showed maximum IAA production. At the same time L-tryptophan concentration for the production of IAA and observed that L-tryptophanderived auxin biosynthesis was enhanced several folds.

\section{Effect of $\mathrm{pH}$ and temperature on IAA production}

The maximum level of IAA production was observed in our selected isolate Pseudomonas VSMKU4050 was $11.50 \mu \mathrm{g} / \mathrm{ml}$ at $\mathrm{pH} 7$ (Figure 2). In our results were agreement with Sarwar et al., (1992) reported, Rhizobium sp. was isolated from root nodules of Vigna mungo was IAA produced maximum at $\mathrm{pH}$ 7.2. Moreover physiochemical variation of media was always specific to organisms for the production biosynthetic secondary metabolites. The alteration of $\mathrm{pH}$ in different media growth microbial metabolic activity has been chanced. Similar results were observed in Bacillus sp. for maximum IAA production at pH 7 (Khamna et al., 2010). In gentral agriculture soil $\mathrm{pH}$ has a significant effect on L - tryptophan-derived IAA production. The application of different fertilizer could be changed $\mathrm{pH}$ of the soil, hence through $\mathrm{pH}$ change reduced the IAA production by rhizobacteria (Yuan et al., 2011). The effect temperature was studied in range 15 to $45^{\circ} \mathrm{C}$. Among them, the maximum production of IAA was observed 
$6.80(\mu \mathrm{g} / \mathrm{ml})$ at $35^{\circ} \mathrm{C}$, followed by $30^{\circ} \mathrm{C}$ (Figure 3). Similar results were shown in other studies where $37^{\circ} \mathrm{C}$ was the best temperature for IAA production by Rhizobium and Bacillus sp. (Sachdev et al., 2009). In addition, similar reports were also support for our studies for IAA production by microbes (Yuan et al., 2011). According to Sudha et al., (2012) $37^{\circ} \mathrm{C}$ temperature was optimum for IAA production by Bacillus and Rhizobium sp.

\section{Effect of different days and medium on} IAA production

IAA production was performed up to four days, among them the maximum IAA production was observed in third day of incubation $(12.80 \mu \mathrm{g} / \mathrm{ml})$ (Figure 4). Recent study by Yousef et al., (2018) showed similar to our findings for maximum IAA production by rhizobacterium in three days of incubation compared to control. Similarly among five different medium for IAA production, the significant amount of IAA production was observed in King's B broth $(9.80 \mu \mathrm{g} / \mathrm{ml})$. Whereas the lowest amount of IAA production was observed in nutrient sucrose broth $(6.80 \mu \mathrm{g} / \mathrm{ml})$ compared to control (Figure 5). Maximum production of the plant growth promoting substance IAA was observed in King's B broth (Shanmugaiah et al., 2006).

\section{Detection of IAA on TLC}

The isolate Pseudomonas sp VSMKU4050 has the ability to produce IAA was confirmed by TLC analysis. As shown in (Figure 6), when the TLC plate was treated with Ehmann reagent, the ethyl acetate extract from culture filtrate showed a clear pink colour spot on the TLC plate at the $\mathrm{Rf}$ value almost similar to standard IAA (0.87). Similar report was observed in Streptomyces sp VSMGT4014 for
IAA production on TLC with similar Rf value (Harikrishnan et al., 2014).

\section{Biophysical characterization of IAA}

The partial purified IAA was observed on the TLC plates with $\mathrm{Rf}$ value 0.87 , which was very similar to the $\mathrm{Rf}$ value of authentic IAA $(0.89)$ at $240 \mathrm{~nm}$ in the ultra violet chamber. The UV spectrum of crude extracts showed $\lambda \max$ at $280 \mathrm{~nm}$ and 320 (Figure 7). FT-IR spectrum of ethyl acetate extracts exhibited absorption at 3420 and $1685 \mathrm{~cm}^{-1}$, which indicated $\mathrm{C}=\mathrm{O}$ and $\mathrm{OH}$ frequency similar functional group were observed in authentic IAA (Figure 8). The UV absorption significantly match with the IAA reported by Andonovski (1999) and Jha et al., (2015). In IR spectrum of IAA of our report, the positions, intensities and profiles of the spectra are in agreement has close resemble with previously reported IAA (De Weerdt et al., 2008).

\section{Plant growth promotion of tomato by Pseudomonas sp VSMKU4050}

The significant results were obtained for plant growth promotion of tomato seedlings in sterilized soil by our isolate VSMKU4050 in seed germination $(80 \%)$, root length $(7.6 \mathrm{~cm})$ and shoot length $(12 \mathrm{~cm})$, fresh and dry weight $(1.80 \mathrm{~g}$ and $0.14 \mathrm{~g})$ vigor index (1568) and number of leaf (11), where as in non sterile soil, the selected strain VSMKU4050 remarkably enhance the seed germination $(90 \%)$, root length $(18.2 \mathrm{~cm})$ and shoot length $(8 \mathrm{~cm})$, fresh and dry weight $(2.1 \mathrm{~g}$ and $0.27 \mathrm{~g})$ vigor index (2358) and number of leaf (12) compared to control. Similarly cell free culture filtrate of VSMKU4050 showed considerable increase in both sterile and non sterile soil grown tomato seedlings compared to control (Table 2 and 3).

Table.1 Physiochemical and biochemical characterization of Pseudomonas sp. VSMKU4050 


\begin{tabular}{|c|c|}
\hline Test & $\begin{array}{c}\text { Result } \\
\text { (Positve+/Negative-) }\end{array}$ \\
\hline Gram staining & Gram negative, Rod \\
\hline Motility & Motile \\
\hline Oxidase & + \\
\hline Catalase & + \\
\hline Citrate utilization & + \\
\hline Nitrate reduction & - \\
\hline Urea & - \\
\hline Indole production & + \\
\hline MR & - \\
\hline VP & - \\
\hline TSI & $\begin{array}{c}\text { Acid butt, Alkaline slant, } \\
\mathrm{H}_{2} \mathrm{~S}, \mathrm{Gas} \text {. }\end{array}$ \\
\hline \multicolumn{2}{|c|}{ Carbohydrate utilization } \\
\hline Glucose & + \\
\hline Galactose & + \\
\hline Sucrose & + \\
\hline Arabinose & - \\
\hline Lactose & - \\
\hline Maltose & - \\
\hline Xylose & - \\
\hline \multicolumn{2}{|c|}{ Lytic enzyme production } \\
\hline Chitinase & - \\
\hline Cellulase & - \\
\hline Protease & + \\
\hline Pectinase & + \\
\hline
\end{tabular}

Table.2 Effect of plant growth promotion by Pseudomonas sp. VSMKU4050 in sterilized soil

\begin{tabular}{|c|c|c|c|c|c|c|c|}
\hline Treatments & $\begin{array}{c}\text { Germinat } \\
\text { ion }(\%)\end{array}$ & $\begin{array}{c}\text { Root } \\
\text { Length }(\mathbf{c m})\end{array}$ & $\begin{array}{c}\text { Shoot } \\
\text { Length } \\
\text { (cm) }\end{array}$ & $\begin{array}{c}\text { Fresh } \\
\text { Weight } \\
\text { (g) }\end{array}$ & $\overrightarrow{0}$ & $\begin{array}{l}\text { No of } \\
\text { Leaf }\end{array}$ & $\begin{array}{l}\text { Vigor } \\
\text { Index }\end{array}$ \\
\hline Treated with Water & 60 & $\begin{array}{c}3.5 \\
\pm 0.512\end{array}$ & $\begin{array}{c}10.2 \\
\pm 0.492\end{array}$ & $\begin{array}{c}0.80 \\
\pm 0.201\end{array}$ & $\begin{array}{c}0.09 \\
\pm 0.012\end{array}$ & 6 & 822 \\
\hline $\begin{array}{l}\text { Treated with sterile } \\
\text { Control Broth }\end{array}$ & 60 & $\begin{array}{c}4.1 \\
\pm 0.442 \\
\end{array}$ & $\begin{array}{c}11.5 \\
\pm 0.461\end{array}$ & $\begin{array}{c}1.00 \\
\pm 0.262\end{array}$ & $\begin{array}{c}0.11 \\
\pm 0.073 \\
\end{array}$ & 8 & 936 \\
\hline $\begin{array}{l}\text { Treated with Culture } \\
\text { Broth }\end{array}$ & 80 & $\begin{array}{c}7.6 \\
\pm 0.152\end{array}$ & $\begin{array}{c}12 \\
\pm 0.112\end{array}$ & $\begin{array}{c}1.80 \\
\pm 0.102\end{array}$ & $\begin{array}{c}0.14 \\
\pm 0.019\end{array}$ & 11 & 1568 \\
\hline $\begin{array}{l}\text { Treated with Culture } \\
\text { filtrate }\end{array}$ & 70 & $\begin{array}{c}4 \\
\pm 0.442\end{array}$ & $\begin{array}{c}9.2 \\
\pm 0.412\end{array}$ & $\begin{array}{c}1.04 \\
\pm 0.302\end{array}$ & $\begin{array}{c}0.12 \\
\pm 0.041\end{array}$ & 10 & 924 \\
\hline Treated with IAA & 80 & $\begin{aligned} & 18.2 \\
\pm & 0.391\end{aligned}$ & $\begin{array}{c}8.2 \\
\pm 0.222\end{array}$ & $\begin{array}{c}1.70 \\
\pm 0.502\end{array}$ & $\begin{array}{c}0.25 \\
\pm 0.439\end{array}$ & 12 & 2376 \\
\hline
\end{tabular}

Values are mean of triplicates with SD

Table.3 Effect of plant growth promotion by Pseudomonas sp. VSMKU4050 in non-sterile soil 


\begin{tabular}{|c|l|c|c|c|c|c|c|c|}
\hline SI No & \multicolumn{1}{|c|}{ Experiments } & $\begin{array}{c}\text { Germinatio } \\
\text { n }(\mathbf{\%})\end{array}$ & $\begin{array}{c}\text { Root } \\
\text { Length } \\
(\mathbf{c m})\end{array}$ & $\begin{array}{c}\text { Shoot } \\
\text { Length } \\
\mathbf{( c m})\end{array}$ & $\begin{array}{c}\text { Fresh } \\
\text { weight } \\
\mathbf{( g )}\end{array}$ & $\begin{array}{c}\text { Dry } \\
\text { weight } \\
\mathbf{( g )}\end{array}$ & $\begin{array}{c}\text { No of } \\
\text { Leaf }\end{array}$ & $\begin{array}{c}\text { Vigor } \\
\text { Index }\end{array}$ \\
\hline $\mathbf{1}$ & Treated with Water & 60 & 16.3 & 5.5 & 1.40 & 0.19 & 6 & 1308 \\
& & & \pm 0.577 & \pm 0.701 & \pm 0.311 & \pm 0.421 & & \\
\hline $\mathbf{2}$ & Treated with sterile & 60 & 16.5 & 5.2 & 1.30 & 0.28 & 6 & 1302 \\
& Control Broth & & \pm 0.502 & \pm 0.5 .32 & \pm 0.133 & \pm 0.411 & & \\
\hline $\mathbf{3}$ & Treated with Culture & 90 & 18.2 & 8 & 2.1 & 0.27 & 12 & 2358 \\
& Broth & & \pm 0.302 & \pm 0.107 & \pm 0.112 & \pm 0.126 & & \\
\hline $\mathbf{4}$ & Cell free culture & 80 & 17 & 7.3 & 1.30 & 0.16 & 10 & 1944 \\
& filtrate & & \pm 0.547 & \pm 0.201 & \pm 0.478 & \pm 0.501 & & \\
\hline $\mathbf{5}$ & Treated with IAA & 90 & 18.2 & 8.2 & 1.70 & 0.25 & 12 & 2376 \\
& & & \pm 0.391 & \pm 0.222 & \pm 0.502 & \pm 0.439 & & \\
\hline
\end{tabular}

Values are mean of triplicates with SD

Fig.1 Effect of L-tryptophan concentration on IAA production

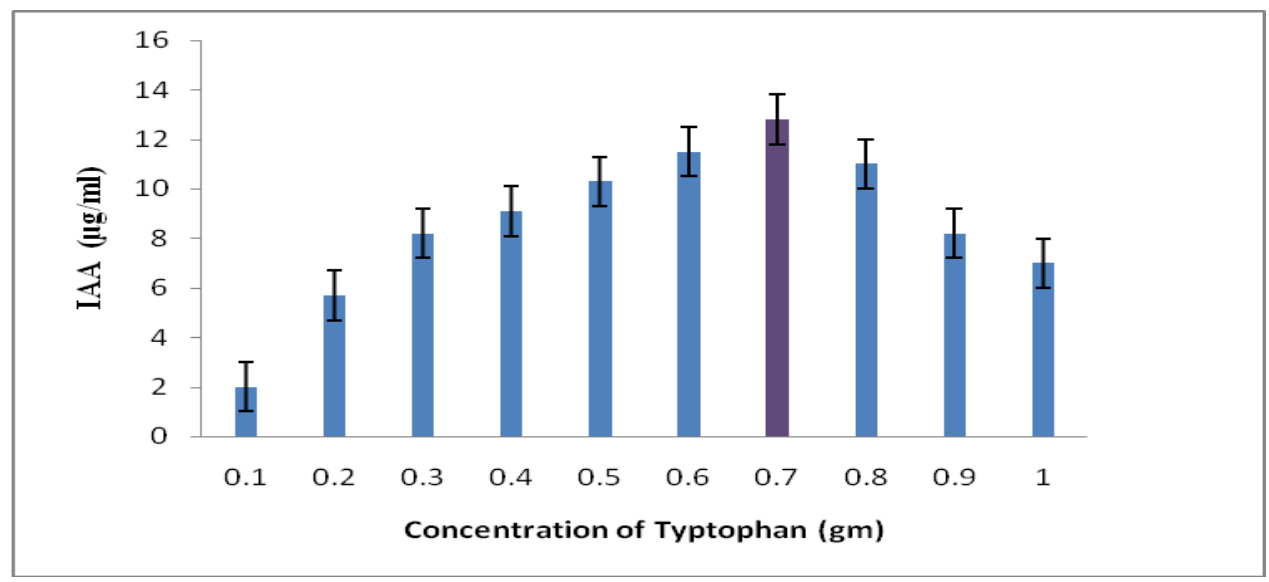

Fig.2 Effect of pH on IAA production

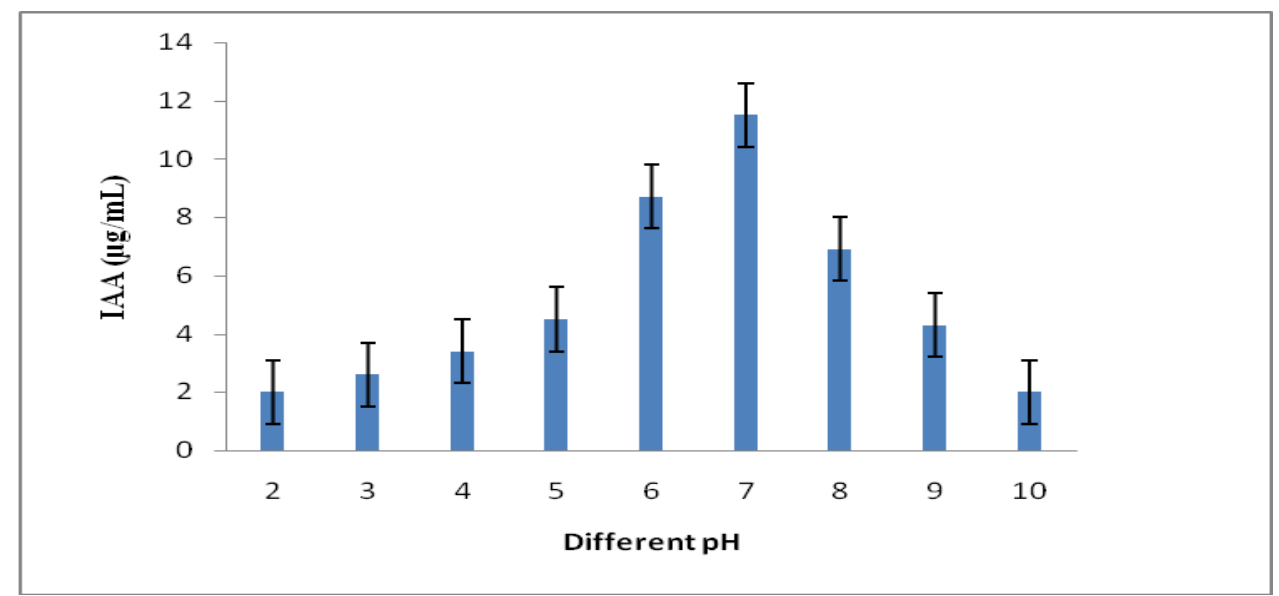

Fig.3 Effect of temperature on IAA production 


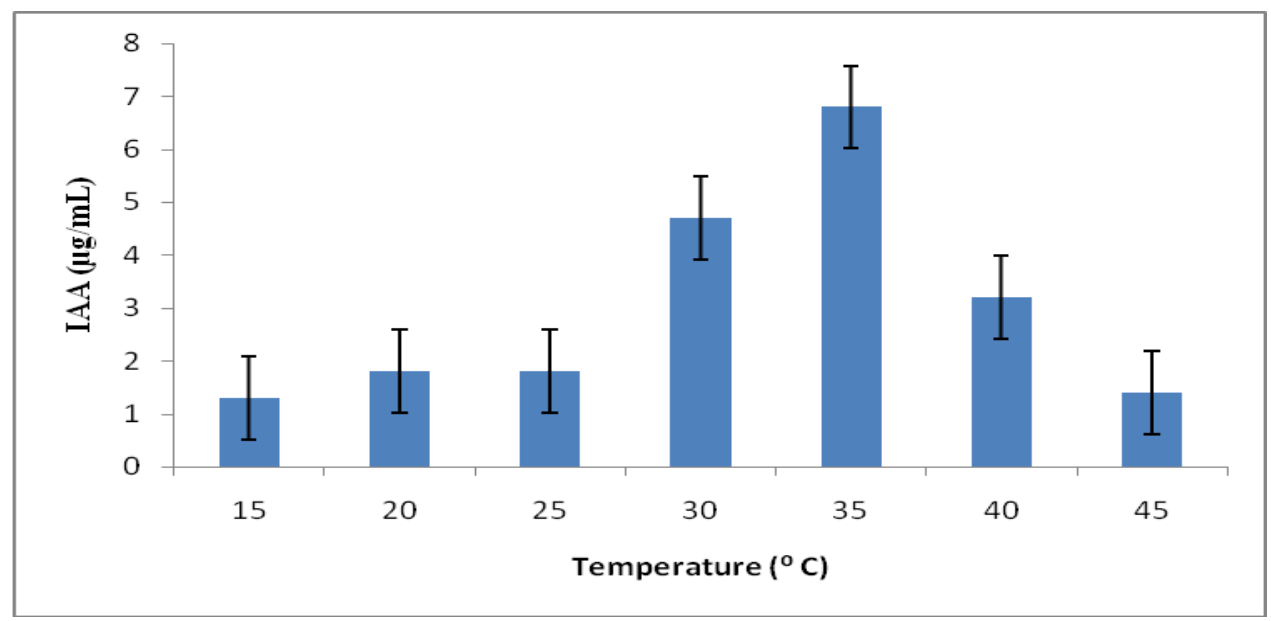

Fig.4 Effect of incubation period on IAA production

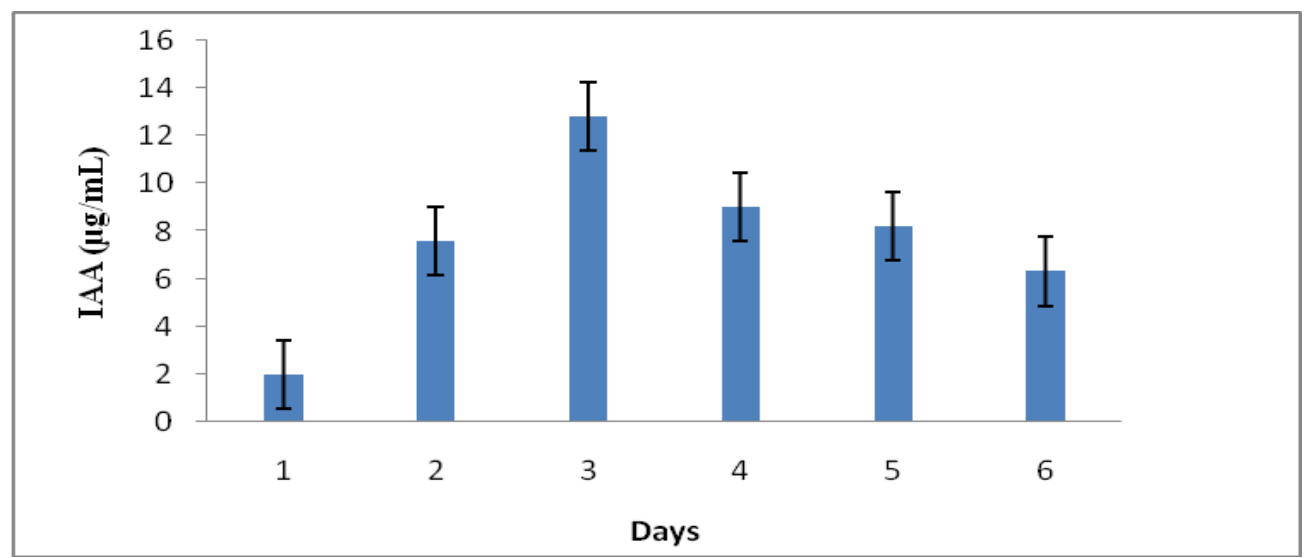

Fig.5 Effect of different medium on IAA production

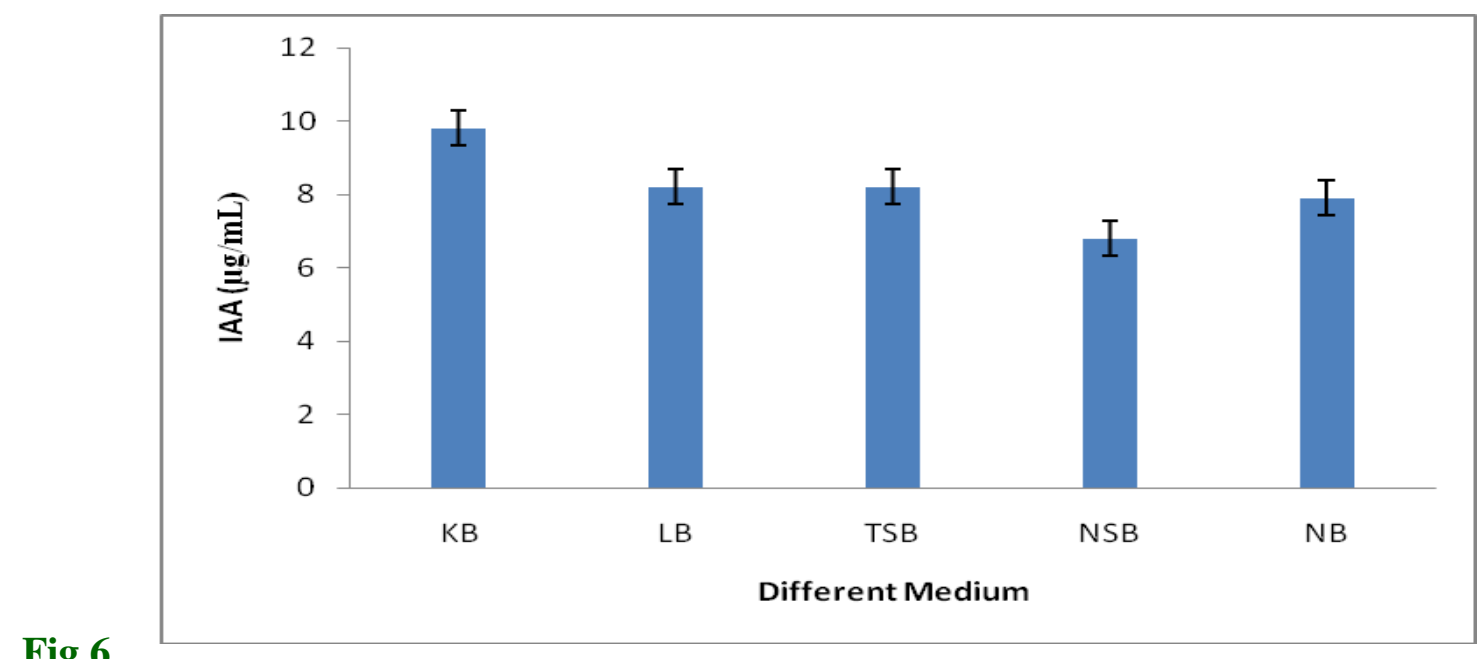

Fig.6

Thin 
layer chromatogram of IAA detected by Salkowiski reagent from crude extract compared with standard

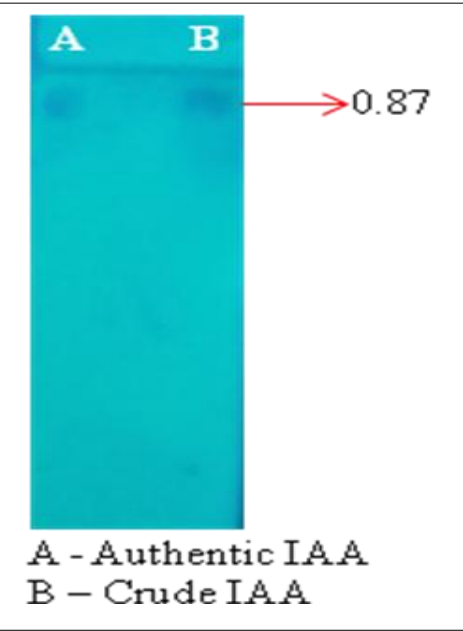

Fig.7 UV Spectrum of crude IAA

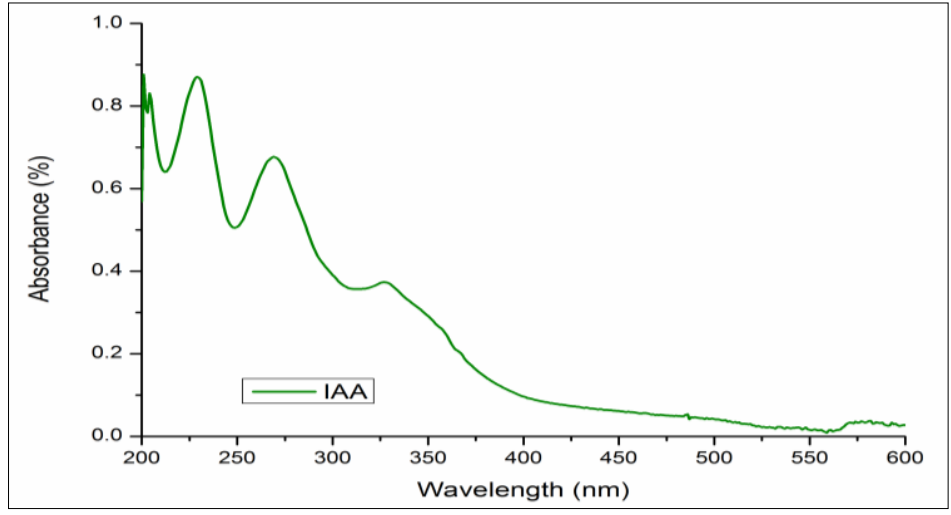

Fig.8 FT-IR Spectrum of crude IAA

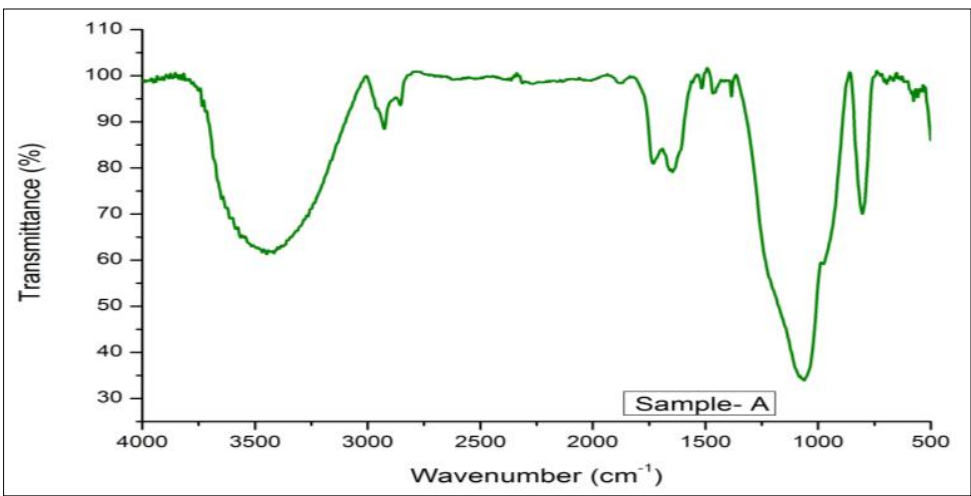


Rhizobacteria is responsible for IAA production because they colonize in the rhizosphere and plant roots as well as reside freely in soil can enhance plant growth by different mechanism. Many microorganisms from rhizosphere region of various crops have an ability to produce IAA as secondary metabolites due to rich supply of substrates. IAA helps in the production of longer roots with increased number of root hairs and root laterals which are involved in nutrient uptake Fatima et al., (2009) also showed that germination rate, roots and shoot growth of plant were increased by IAA and PGPR. Therefore isolate VSMKU4050 was studied for their effect on plant growth under controlled conditions. It is concluded that, the presence of such growth promoting rhizoflora accountable for the beneficial effects on crop growth and yield. The significance of the study could be stated as the potential of these IAA producing isolates and optimization study for IAA production will flourish the growth and ultimately. IAA production in the field and prevent environmental pollution by avoiding excessive applications of industrially produced fertilizers to cultivated fields.

\section{Acknowledgement}

The authors greatly acknowledge The Coordinator, NRCBS and School of Biological Sciences, Madurai Kamaraj University, Madurai, for providing laboratory and instruments facilities.

\section{References}

Ahemad M, Kibert M. Mechanisms and applications of plant growth promoting rhizobacteria: current perspective. A review. Saudi J Biol Sci. 2014; 26: 120.

Andonovski, B.S., 1999. UV Study of the Protonation of indole-2-carboxylic acid, 3-methylindole, 3-acetylindole and Dtryptophan in perchloric acid solutions. Croatica Chemica Acta, 72(4), pp.711-726.

Arshad M, Frankenberger WT. 1992. Microbial production of plant growth regulators. In: Meeting FB Jr (eds). Soil Microbial Ecology, Marcel Dekker Inc., New York. pp. 307-347.

Barbieri, P.; Zanelli, T.; Galli, E. and Zanetti, G. 1986. Wheat inoculation with Azospirillum brasilense Sp6 and some mutans altered in nitrogen fixation and indole-3-aceticacid production. Microbiol. Lett., 36, 87-90.

Charulatha, R Harikrishnan,H, Manoharan,P.T and Shanmugaiah, V. 2013. Characterization of Groundnut rhizosphere Pseudomonas sp VSMKU 2013 for control of phytopathogens. In: Microbiological research in agroecosystem management, Velu, Rajeshkannan (Eds). Springer India.121127.

Datta C, Basu PS. 2000. Indole acetic acid production by a Rhizobium species from root nodules of a leguminous shrub, Cajanus cajan. Microbiol Res 155:123127.

De Weerdt, F. Collins A.T. 2008. Determination of the $\mathrm{C}$ defect concentration in HPHT annealed type IaA diamonds from UV-VIS absorption spectra. Diamond \& Related Materials 17; 171-173.

Ehmann, A. 1977. The van Urk-Salkowski reagent. A sensitive and specific chromogenic reagent for silica gel thin layer chromatographic detection and identification of indole derivatives. J Chromatogr. 132: 267- 276.

Fatima, S., A. Mujib, S.A. Nasim and Z.H. Siddiqui, 2009. Cryopreservation of embryogenic cell suspensions of Catharanthus roseus L. (G) Don. Plant Cell Tiss. Org. Cult., 98: 1-9.

Finnie, J. F. and Van Staden, J. 1985. Effect of seed weed concentrate and applied hormones on in vitro cultured tomato roots. J Plant Physiol. 120: 215- 222.

Glick B.R., Brooks H.E., Pasternak J.J., 1986. Physiological effects of plasmid DNA 
transformation of Azotobacter vinelendi. Canadian Journal of Microbiology 32: 145-148.

Harikrishnan, H., Shanmugaiah, V., Balasubramanian, N., Sharma, M.P and Kotchoni, S.O. 2014. Antagonistic potential of native strain Streptomyces aurantiogriseus VSMGT1014 against sheath blight of rice disease. $W . J$. Microbiol. Biotech. 30: 3149-3161.

Jha, C.K. and Saraf, M., 2015. Plant growth promoting rhizobacteria (PGPR): a review. Journal of Agricultural Research and Development, 5(2), 108-119.

Khamna, S., Yokota, A. and Peberdy, J. F. 2010. Indole-3-acetc acid production by Streptomyces sp. isolated from some Thai medicinal plant rhizosphere soils. Eurasian J Biosciences. 4: 23- 31.

Mahdi SS. Hassan G., Samoon SA Rather HA. Dar SA, Zehra B. 2010. Bio-fertilizers in organic agriculture. Journal of Phytology 2(10)

Patten CL, Glick BR. 1996. Bacterial biosynthesis of indole-3-acetic acid. Can J Microbiol 42:207-220.

Patten CL, Glick BR. 2002. Regulation of indole acetic acid production in Pseudomonas putida GR12-2 by tryptophan and the stationary phase sigma factor RpoS. Can J Microbiol 48:635642.

Patten, C. L and Glick, B.R. 2002 Role of Pseudomonas putida indole acetic acid in development of the host plant root system. Appl Environ Microbiol. 68: 3795-3801.

Rifat Hayat, Safdar Ali, Ummay Amara, Rabia Khalid, Iftikhar Ahmed. 2010. Soil beneficial bacteria and their role in plant growth promotion: a review. Ann Microbiol. 60: 579- 598.

Sachdev D, Chaudhari H, Kasture V, Dhavale D, Chopade B. 2009. Isolation and characterization of indole acetic acid (IAA) producing Klebsiella pneumoniae strains from rhizosphere of wheat (Triticum aestivum) and their effect on plant growth. Indian Journal of
Experimental Biology. Vol. 47, pp. 9931000.

Santi, M. Keshab, C. Dey, S. and Pati, B. R. 2007. "Optimization of cultural and nutritional conditions for indole acetic acid production by a Rhizobium sp. isolated from root nodules of Vigna mungo (L.) Hepper," Res. J. Microbiol., vol. 2, no. 3, pp. 239-246.

Sarwar, M. and Kremmer, R. J. Enhanced suppression of plant growth through production of L- tryptophan- derived compounds by deleterious rhizobacteria. Plant and Soil. 172: 261- 269.

Shanmugaiah, V., Mathivanan. N. and Varghese, B. 2010. Purification, crystal structure and antimicrobial activity of phenazine-1-carboxamide produced by a growth-promoting biocontrol bacterium, Pseudomonas aeruginosa MML2212. Journal of Applied Microbiology. 108: 703- 711 .

Shanmugaiah, V., Ramesh, S., Jayaprakashvel, M. and Mathivanan, N. 2006. Biocontrol and plant growth promoting potential of a Pseudomonas sp. MML2212 from the rice rhizosphere. In: Proceedings for the $1^{\text {st }}$ International Symposium on Biological Control of Bacterial Plant Diseases. (Ed. Zeller, W., and Ullrich, C.). Federal Institute of Biological Control, Dormstadt, Germany. pp. 320-324.

Shanmugaiah, V., Balasubramanian,N., Gomathinayagam, S., Manoharan, P.T and Rajendran, A. 2008. Effect of Pseudomonas fluorescens and Trichoderma viride on growth promotion in Sorghum. Ind. J. Bot. Res. 4 (3 \& 4): $453-460$.

Shanmugaiah, V., Balasubramanian, N., Gomathinayagam, S., Manoharan, P.T and Rajendran, A. 2009. Effect of single application of Trichoderma viride and Pseudomonas fluorescens on growth promotion in cotton. African Journal of Agricultural Research: 4(11): 1220-1225.

Singh JS, Pandey VC, Singh DP. 2011. Efficient soil microorganisms: a new 
dimension for sustainable agriculture and environmental development. Agric Ecosyst Environ., 140(3): 339-353.

Spaepen S, Vanderleyden J, Remans R. 2007. Indole-3-acetic acid in microbial and microorganism plant signaling. FEMS Microbiol Rev., 31: 425-448.

Spencera Matthew. Choong-Min Ryub. Yanga Kwang-Yeol. Cheol Kimc Young. Kloepperb Joseph W. Anderson Anne J. 2003. Induced defense in tobacco by Pseudomonas chlororaphis strain O6 involves at least the ethylene pathway. Mol. Plant Microbe Interact. 63:27-34

Stein, A., Fortin, J. A. and Vallee, G. 1990. Enhanced rooting of Picea mariana cuttings by ecto mycorrhizal fungi. Can $J$ Bot. 68: 492-498.

Sudha, M., Shyamala, G.R., Prabhavati, P., Astapritya, P., Yamuna Devi, Y. and Saranya, A. 2012. Production and optimization of Indole acetic acid by indigenous micro flora using agro waste as substrate. Pak J of Biol Sci. 15: 39- 43.

Swetha, S. and Padmavathi, T., 2016. Biosynthesis, Characterization and Optimization of Auxins by Piriformospora indica: It's Impact on Growth of Solanum melongena L. Cultivars. Journal of Scientific and industrial research. Vol 75, pp 45-50.

Wahyudi A T, Astuti R P, Widyawati A, Meryandini A, Nawangsih AA. 2011 Characterization of Bacillus sp. Strains isolated from rhizosphere of soybean plants for their use as potential plant growth for promoting Rhizobacteria. Journal of Microbiology and Antimicrobials. Vol. 3, pp. 34-40.

Yokota S, A, Peberdy JF, Lumyong S. Indole3acetic acid production by Streptomyces sp. isolated from some Thai medicinal plant rhizosphere soils. Eur Asia J BioSci. 2010 ; 4: 23-32.

Yousef, N.M.H. 2018. Capability of plant growth-promoting rhizobacteria (PGPR) for producing indole acetic acid (IAA) under extreme conditions. European Journal of Biological Research: 8 (4): 174-182.

Yuan, C. L. Mou, C. X. Wu, W. L. and Guo, Y. B.. 2011. "Effect of different fertilization treatments on indole-3-acetic acid producing bacteria in soil," J. Soils Sediments, vol. 11, no. 2, pp. 322-329.

Zhao, Y. 2010. Auxin biosynthesis and its role in plant development. Annul Rew. Pla. Biology. 61:49- 64.

\section{How to cite this article:}

Kalimuthu, R., P. Suresh, G. Varatharaju, N. Balasubramanian, K.M. Rajasekaran and Shanmugaiah, V. 2019. Isolation and Characterization of Indole Acetic Acid (IAA) Producing Tomato Rhizobacterium Pseudomonas sp VSMKU4050 and its Potential for Plant Growth Promotion. Int.J.Curr.Microbiol.App.Sci. 8(06): 443-455. doi: https://doi.org/10.20546/ijcmas.2019.806.050 